\title{
Deep-sea manefishes (Perciformes: Caristiidae) from oceanic islands and seamounts off northeastern Brazil, with comments on the caristiids previously reported in Brazilian waters
}

\author{
Mincarone Michael M. ${ }^{1,}{ }^{*}$, Villarins Bárbara T. ${ }^{1}$, Eduardo Leandro N. ${ }^{2,3}$, Caires Rodrigo A. ${ }^{4}$, \\ Lucena-Frédou Flavia ${ }^{2}$, Frédou Thierry ${ }^{2}$, Lira Alex Souza ${ }^{2}$, Bertrand Arnaud ${ }^{2,3}$
}

\footnotetext{
1 Instituto de Biodiversidade e Sustentabilidade, Universidade Federal do Rio de Janeiro, Macaé, Brazil

2 Departamento de Pesca e Aquicultura, Universidade Federal Rural de Pernambuco, Recife, Brazil

3 Institut de Recherche pour le Développement, MARBEC, Sète, France

${ }^{4}$ Museu de Zoologia da Universidade de São Paulo, São Paulo, Brazil

* Corresponding author : Michael M. Mincarone, email address : mincarone@macae.ufri.br
}

\begin{abstract}
:
The manefishes of the family Caristiidae are rare, poorly known deep-sea species with broad geographical distribution. This study provides new information on the diversity and distribution of this family around the oceanic islands and seamounts off northeastern Brazil, reporting the first records of Paracaristius nudarcus, Platyberyx andriashevi, Platyberyx paucus and Platyberyx pietschi in Brazilian waters. Measurements and counts for all specimens examined are provided and compared with those available in the literature. In addition, the identity of caristiids previously reported from Brazil is discussed.
\end{abstract}

Keywords : Paracaristius, Platyberyx, mesopelagic fish, Brazil, western South Atlantic 


\section{Introduction}

27 Fishes of the family Caristiidae are rare deep-sea species with broad geographical distribution, 28 occurring in all oceans (Kukuev et al. 2013; Stevenson \& Kenaley, 2013). The family comprises 29 four genera and 18 species commonly known as manefishes (Stevenson \& Kenaley, 2013). 30 These species present epipelagic larvae and juveniles, occurring from the surface to the 
mesopelagic zone, while adults have been reported at depths ranging from 100 to $2000 \mathrm{~m}$

32 (Benfield et al., 2009; Stevenson \& Kenaley, 2011, 2013). The caristiids are characterized by having relatively short heads, steep snouts, large eyes, deep and strongly compressed bodies, very long and high dorsal fins and greatly elongated pelvic fins (Benfield et al., 2009; Kukuev et al., 2013; Stevenson \& Kenaley, 2013).

Studies on the taxonomy and distribution of caristiids were historically scarce and fragmented. However, a series of taxonomic revisions has been recently conducted (Kukuev et al., 2012, 2013; Stevenson \& Kenaley, 2011, 2013) and the knowledge on the taxonomy and the distribution patterns was significantly improved. The family Caristiidae is currently divided into two distinctly pronounced groups: Paracaristiinae and Caristiinae. The Paracaristiinae comprises two genera (Neocaristius and Paracaristius) and five species usually known as "small-mouth" caristiids (Stevenson \& Kenaley, 2011), while the Caristiinae, in turn, includes two genera (Caristius and Platyberyx) and 13 species referred to as "large-mouth" caristiids (Stevenson \& waters based on specimens collected around Rocas Atoll, Fernando de Noronha Archipelago, and sea mounts off Rio Grande do Norte. Meristic and morphometric data are provided for all specimens examined, and the identity of caristiids previously reported in Brazilian waters is

\section{Materials and Methods}

The material examined in the current study is part of a large collection of mesopelagic invertebrates and fishes sampled during the ABRACOS expeditions (Acoustics along the BRAzilian COaSt), carried out in October 2015 and April 2017 and conducted by the French RV Antea off northeastern Brazil, including Rocas Atoll, Fernando de Noronha Archipelago, and seamounts off Rio Grande do Norte (Fig. 1). The extensive survey in 80 fishing stations from 0 to $1113 \mathrm{~m}$ depth resulted in the collection of 11 specimens of Caristiidae, of which seven where identified at species level. Sampling was conducted using micronekton (body mesh: $40 \mathrm{~mm}$, codend mesh: $10 \mathrm{~mm}$ ) and mesopelagic (body mesh: $30 \mathrm{~mm}$, cod-end mesh: $4 \mathrm{~mm}$ ) nets. Trawl depth was continuously recorded using a Scanmar depth sensor fitted on the upper part of the trawl mouth. 
Measurements and counts were mostly taken according to Hubbs \& Lagler (1947). In

63 addition, "preorbital length" and "predorsal length" were measured along the body axis

64 ("horizontal distance"), from the tip of the snout to a vertical line passing through the anterior

65 margin of orbit (preorbital) and through the dorsal-fin origin (predorsal). This was necessary for

66 comparison with data provided by Stevenson \& Kenaley $(2011,2013)$ (Duane Stevenson \&

67 Christopher Kenaley, pers. comm.). Radiographs of specimens were taken using a Faxitron LX-

6860 to aid fin-rays and vertebrae counts. Specimens were identified according to the keys

69 provided by Stevenson \& Kenaley (2011) and Stevenson \& Kenaley (2013). All specimens

70 examined were deposited at NPM - Fish Collection of the Núcleo em Ecologia e

71 Desenvolvimento Socioambiental de Macaé, Universidade Federal do Rio de Janeiro (Macaé,

72 RJ, Brazil).

\section{Results}

75

\section{Family Caristiidae}

77

Genus Paracaristius Trunov, Kukuev \& Parin, 2006

\section{Paracaristius nudarcus Stevenson \& Kenaley, 2011}

81 (Fig. 1)

82

Material Examined. NPM 4476 (1 specimen, 165 mm SL), RV Antea, ABRACOS \#41A, Brazil, off northern Fernando de Noronha Archipelago, 0319'59'S, 32²4'42'W to 0319’32”S, 32²5’05”W, 0-430 m depth, micronekton trawl net, 26 April 2017, 21:44-22:06h.

Diagnoses. According to Stevenson \& Kenaley (2011), Paracaristius nudarcus can be 88 distinguished from $P$. aquilus and $P$. nemorosus by the absence of fingerlike papillae along the 89 dorsal margin of the hyoid arch and at the interhyal-posterior ceratohyal articulation, as well as dorsal-fin rays (27-31 vs. 30-33) and anal-fin rays (17-20 vs. 15-18) counts. Paracaristius nudarcus can be distinguished of $P$. maderensis by the position of the dorsal-fin origin (above 
orbit vs. posterior to orbit) and by the arrangement of the jaw teeth (single row, except near symphyses vs. multiple rows).

Distribution. Paracaristius nudarcus has been previously reported in the western North Atlantic, eastern South Atlantic, eastern Indian Ocean, and eastern and western Pacific (Stevenson \& Kenaley, 2011). The specimen reported off northern Fernando de Noronha Archipelago represents the first record of the genus and species in the western South Atlantic (Fig 2).

Remarks. Morphometric and meristic data for the specimen reported herein are within the range to those recorded by Stevenson \& Kenaley (2011) (Table I).

Genus Platyberyx Zugmayer, 1911

Platyberyx andriashevi (Kukuev, Parin \& Trunov, 2012) (Fig. 3a)

Material Examined. NPM 4473 (1, 138 mm SL), RV Antea, ABRACOS \#44A, Brazil, off

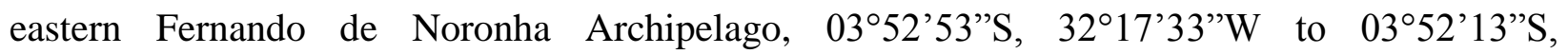
32²6'28”'W, 0-850 m depth, micronekton trawl net, 28 April 2017, 12:44-13:17h. NPM 4475 (2, 23-33 mm SL), RV Antea, ABRACOS \#40B, Brazil, off northern Fernando de Noronha Archipelago, $03^{\circ} 31^{\prime} 12^{\prime \prime} \mathrm{S}, 32^{\circ} 31^{\prime} 49^{\prime \prime} \mathrm{W}$ to $03^{\circ} 31^{\prime} 03^{\prime} \mathrm{S}, 32^{\circ} 32^{\prime} 49^{\prime \prime} \mathrm{W}, 0-230 \mathrm{~m}$ depth, micronekton trawl net, 26 April 2017, 12:14-12:37h.

Diagnoses. According to Stevenson \& Kenaley (2013), Platyberyx andriashevi may be distinguished from all congeners by the following combination of characters: 36 or more vertebrae, 31 or more dorsal-fin rays, and 20 or more anal-fin rays. Platyberyx andriashevi may be further distinguished from its congeners, except $P$. paucus and $P$. pietschi, by the presence of laterally flattened, bladelike ventral procurrent caudal rays, and an anteriorly directed hook-like process on the third posterior-most ventral procurrent caudal ray. 
123 Distribution. Platyberyx andriashevi has been previously reported in the north and southeast

124 Atlantic, north and southwest Pacific, and Indian Ocean (Stevenson \& Kenaley 2013; Okamoto $\&$ Stevenson 2015). The specimens reported around Fernando de Noronha Archipelago represent the first record of Platyberyx andriashevi in the western South Atlantic (Fig. 2).

Remarks. Considering the high meristics and rigidly fixed jaw teeth of $P$. andriashevi, which argue for placement within the genus Caristius, the species was first described as Caristius andriashevi Kukuev, Parin \& Trunov, 2012. However, due to the presence of a conspicuous lateral line, and its caudal skeleton similar to that of $P$. paucus and P. pietschi, Stevenson \& Kenaley (2013) placed the species into the genus Platyberyx.

Morphometric and meristic data for the specimens reported herein were within the range of those recorded by Stevenson \& Kenaley (2013), except for the number of pectoral-fin rays (19 vs. 17-18), and the peduncle length (8.5-13.0 vs. 12.0-18.9\%SL), respectively (Table I).

\section{Platyberyx paucus Stevenson \& Kenaley, 2013}

(Fig. 3b)

Material Examined. NPM 4474 (1, 85 mm SL), RV Antea, ABRACOS \#44A, Brazil, off

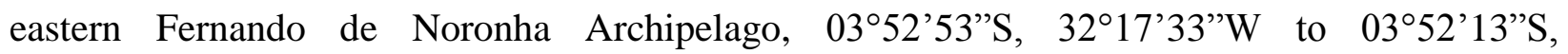
32²6’28’W, 0-850 m depth, micronekton trawl net, 28 April 2017, 12:44-13:17h. NPM 4511 (1, $97 \mathrm{~mm}$ SL), RV Antea, ABRACOS \#35, Brazil, sea mounts off Rio Grande do Norte,

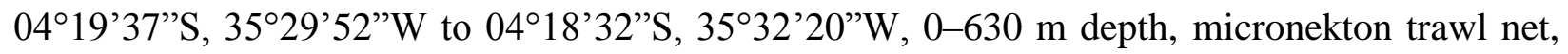
20 April 2017, 22:35-23:15h. NPM 4512 (1, 91 mm SL), RV Antea, ABRACOS \#39, Brazil, off

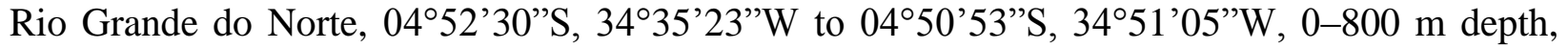
micronekton trawl net, 24 April 2017, 21:49-22:37h.

Diagnoses. According to Stevenson \& Kenaley (2013), Platyberyx paucus can be distinguished from all congeners by the following combination of characters: absence of palatine teeth and lower meristics (31 vertebrae, 24-26 dorsal-fin rays, and 15-16 anal-fin rays). It can be further distinguished from all congeners, except $P$. andriashevi and $P$. pietschi, by the presence of 
laterally flattened, bladelike ventral procurrent caudal rays, and an anteriorly directed hook-like process on the third posterior-most ventral procurrent caudal ray (Stevenson \& Kenaley, 2013).

Distribution. Platyberyx paucus is poorly known worldwide, reported from one specimen in the central North Pacific (Hawai'i, western O'ahu Island), and three specimens from the western Central Atlantic (off northern South America) (Stevenson \& Kenaley, 2013). The current study reports the occurrence of three specimens off Rio Grande do Norte and around Fernando de Noronha Archipelago, which represent the first record of P. paucus in Brazilian waters (Fig. 2).

Remarks. Most of characters observed in our material $(n=3)$ are within the ranges presented for the types of Platyberyx paucus $(\mathrm{n}=4)$. However, some measurements (head length, lower jaw length, prepectoral length, prepelvic length, and preanal length) of the specimens reported herein were smaller than those recorded by Stevenson \& Kenaley (2013) (Table I).

\section{Platyberyx pietschi Stevenson \& Kenaley, 2013}

(Fig 3c)

Material Examined. NPM 4510 (1, 72 mm SL), RV Antea, ABRACOS \#35, Brazil, sea mounts off Rio Grande do Norte, $04^{\circ} 19^{\prime} 37^{\prime \prime S}, 35^{\circ} 29^{\prime} 52^{\prime \prime} \mathrm{W}$ to $04^{\circ} 18^{\prime} 32^{\prime \prime} \mathrm{S}, 35^{\circ} 32^{\prime} 20^{\prime \prime} \mathrm{W}, 0-630 \mathrm{~m}$ depth, micronekton trawl net, 20 April 2017, 22:35-23:15h.

Diagnoses. According to Stevenson \& Kenaley (2013), Platyberyx pietschi can be distinguished from its congeners, except $P$. andriashevi and $P$. paucus, by the presence of an anteriorly directed hook-like process on the third posteriormost ventral procurrent caudal ray. Platyberyx pietschi can be distinguished from $P$. andriashevi by having fewer dorsal-fin rays (30-31 vs. 3137), anal-fin rays (18-19 vs. 19-22), and vertebrae (33-35 vs. 36-39); and from P. paucus by having greater number of dorsal-fin rays (30-31 vs. 24-26), anal-fin rays (18-19 vs. 15-16), pectoral-fin rays (17-18 vs. 16-17), and vertebrae (33-35 vs. 31 ), respectively.

Distribution. Platyberyx pietschi is a poor known species, reported only from two specimens from the western Central Atlantic, one specimen from the central Pacific, and one from the 
western South Pacific (Australia). The specimen currently reported off Rio Grande do Norte represents the first record of P. pietschi in the western South Atlantic (Fig. 2).

Remarks. Morphometric and meristic data for the specimen reported herein were within the range of those recorded by Stevenson \& Kenaley (2013), except by its number of anal-fin rays (17 vs. 18-19), dorsal-fin base length (73.6 vs. 62.9-68.7 \% SL), and lower jaw length (42.9 vs. 55.6-70.7 \% HL), respectively (Table I).

\section{Discussion}

Among more than 7000 mesopelagic fish specimens caught during the two ABRACOS expeditions (October 2015 and April 2017), only 11 specimens of caristiids were collected, of which four could not be identified as they were in poor condition. Of the eighteen species of the family Caristiidae known to date, four have been reported for the first time in Brazilian waters: Paracaristius nudarcus, Platyberyx andriashevi, Platyberyx paucus and Platyberyx pietschi.

In addition to the caristiids reported herein, a few specimens have been previously recorded off Brazilian coast. Caires et al. (2008) recorded two specimens of Caristius collected off southern Brazil. The first one (MZUSP 93287) was identified as Caristius macropus (Bellotti, 1903), collected off State of Rio Grande do Sul, at 32 58'S, 50³5’W, 99 m depth; and the second (MZUSP 86699) was named as Caristius sp., collected off State of São Paulo, at $26^{\circ} 19^{\prime} 49^{\prime \prime} \mathrm{S}, 45^{\circ} 57^{\prime} 00^{\prime \prime} \mathrm{W}, 600 \mathrm{~m}$ depth. The authors, however, recognized the identification of both specimens was tentative due to the lack of taxonomic revisions available at that time. Based on the recent reexamination of the specimens reported by Caires et al. (2008), Caristius macropus and Caristius sp. are herein reidentified as Platyberyx andriashevi and Platyberyx pietschi, respectively, extending the known distribution of both species to off southern Brazil.

Carvalho-Filho et al. (2009) also reported another caristiid, named Caristius sp., in the stomach content of a tropical pomfret Eumegistus brevorti (Poey 1860) (Bramidae), caught off State of Bahia, northeast Brazil. Unfortunately, we did not have access to this material and some important characters that allow identification are not visible on the picture (fig. 5) of the halfdigested specimen.

Despite we consistently used two nets (micronekton and mesopelagic), specimens reported herein were caught only with the micronekton net, which has a greater mesh size and 
214

215

216

217

218

219

220

221

222

223

224

225

226

227

228

229

230

231

232

233

234

235

236

237

238

239

240

241

242

243

244

seems to have a higher fishing efficiency for caristiids. This has also been found in many mesopelagic studies (e.g. Pakhomov \& Yamamura 2010, Heino et al., 2011), where catch efficiency significantly differs among trawl types due to various influences from extrusion through meshes and net avoidance behavior (Kaartvedt et al., 2012). Thus, we believe the diversity of Caristiidae species observed here is not only a consequence of biogeographic patterns of this group, but also reflects the selectivity of sample methods employed. Further, as most of the Brazilian deep waters remain unexplored the current knowledge on the diversity of Caristiidae occurring in the region is probably underestimated. Additional deep-water sampling over banks, continental slopes, seamounts, and near oceanic islands would likely uncover new information on species composition and distribution of the family Caristiidae.

\section{Acknowledgment}

We acknowledge the French oceanographic fleet for funding the at-sea survey ABRACOS (http://dx.doi.org/10.17600/15005600/ http://dx.doi.org/10.17600/17004100) and the officers and crew of the RV Antea for their contribution to the success of the operations. Thanks also to Dr. Paulo Eurico Travassos for the hard work in samples collection. The present study could not have been done without the work of all team members from BIOIMPACT (UFRPE) and LIZ (NUPEM/UFRJ) labs. We thank the CNPq (Brazilian National Council for Scientific and Technological Development), for providing student scholarship to LNE and ASL and research grant to FLF. This work is a contribution to the LMI TAPIOCA and to the PADDLE project, which has received funding from the European Union's Horizon 2020 research and innovation program (grant agreement 73427).

\section{References}

Benfield, M.C., Caruso, J.H. \& Sulak, K.J. (2009) In Situ video observations of two Manefishes (Perciformes: Caristiidae) in the mesopelagic zone of the northern Gulf of Mexico. Copeia 2009, 637-641.

Caires, R.A., Figueiredo, J.L. \& Bernardes, R.A. (2008) Registros novos e adicionais de teleósteos marinhos na costa brasileira. Papéis Avulsos de Zoologia 48, 213-225.

Carvalho-Filho, A., Marcovaldi, G., Sampaio, C. L. S., Paiva, M. I. G. \& Duarte, L. A. G. 2009. First report of rare pomfrets (Teleostei: Bramidae) from Brazilian waters, with a key to 
western Atlantic species. Zootaxa, 2290, 1-26.

Figueiredo, J.L., Santos, A., Yamaguti, N., Bernardes, R. \& Rossi-Wongtschowski, C.L.D. (2002) Peixes da Zona Econômica Exclusiva da região sudeste-sul do Brasil: levantamento com rede de meia-água. Editora da Universidade de São Paulo, São Paulo.

Heino, M., Porteiro, F.M., Sutton, T.T., Falkenhaug, T., Godø, O.R. \& Piatkowski, U. (2011) Catchability of pelagic trawls for sampling deep-living nekton in the mid-North Atlantic. ICES Journal of Marine Science 68, 377-389.

Kaartvedt, S., Staby, A. \& Aksnes, D.L. (2012) Efficient trawl avoidance by mesopelagic fishes causes large underestimation of their biomass. Marine Ecology Progress Series 456, 1-6.

Kukuev, E.I., Parin, N.V \& Trunov, I.A. (2012) Materials for the revision of the family Caristiidae (Perciformes). 2. Manefishes from the East Atlantic (Redescription of Platyberyx opalescens Zugmayer and description of two new species Platyberyx mauli sp. n. and Caristius andriashevi. Journal of Ichthyology 52, 185-199.

Kukuev, E.I., Parin, N.V. \& Trunov, I.A. (2013) Materials for the revision of the family Caristiidae (Perciformes ): 3 . Manefishes (Genus Caristius ) from moderate warm waters of the Pacific and Atlantic Oceans with a description of three new species from the Southeast Atlantic (C. barsukovi sp.n., C. litvinovi sp.n., C. walvisensis sp. n.). Journal of Ichthyology $53,541-561$.

Okamoto, M., Duane E., S. \& Motomura, H. (2014) First record of Paracaristius maderensis from the central North Pacific and a second specimen of Platyberyx rhyton (Perciformes: Caristiidae). Biogeography 16, 23-29.

Okamoto, M. \& Stevenson, D.E. (2015) Records of two manefishes, Platyberyx andriashevi and P. rhyton (Teleostei: Perciformes: Caristiidae), from off the Ogasawara Islands, Japan. Species Diversity 20, 13-17.

Pakhomov, E.A., Yamamura, O., Brodeur, R.D., Domokos, R., Owen, K.R., Pakhomova, L.G., Polovina, J., Seki, M. \& Suntsov, A.V (2010) 38 PICES Scientific Report of the Advisory Panel on Micronekton Sampling Inter-calibration Experiment. North Pacific Marine Science Organization (PICES), Sidney, Canada.

Post, A. (1990) Caristiidae. In: J.-C. Quero, J. C. Hureau, A. P. C. Karrer, and L. Saldanha (Eds), Check-list of the Fishes of the Eastern Tropical Atlantic. Unesco, Paris, pp. 765-766.

Stevenson, D.E. \& Kenaley, C.P. (2011) Revision of the Manefish Genus Paracaristius 
281

282

283

284

285

286

287

288

289

290

291

292

293

294

295

296

297

298

299

300

301

302

303

304

305

306
(Teleostei: Percomorpha: Caristiidae), with Descriptions of a New Genus and Three New Species. Copeia 3, 385-399.

Stevenson, D.E. \& Kenaley, C.P. (2013) Revision of the Manefish Genera Caristius and Platyberyx (Teleostei: Percomorpha: Caristiidae), with Descriptions of Five New Species. Copeia 2013, 415-434. 


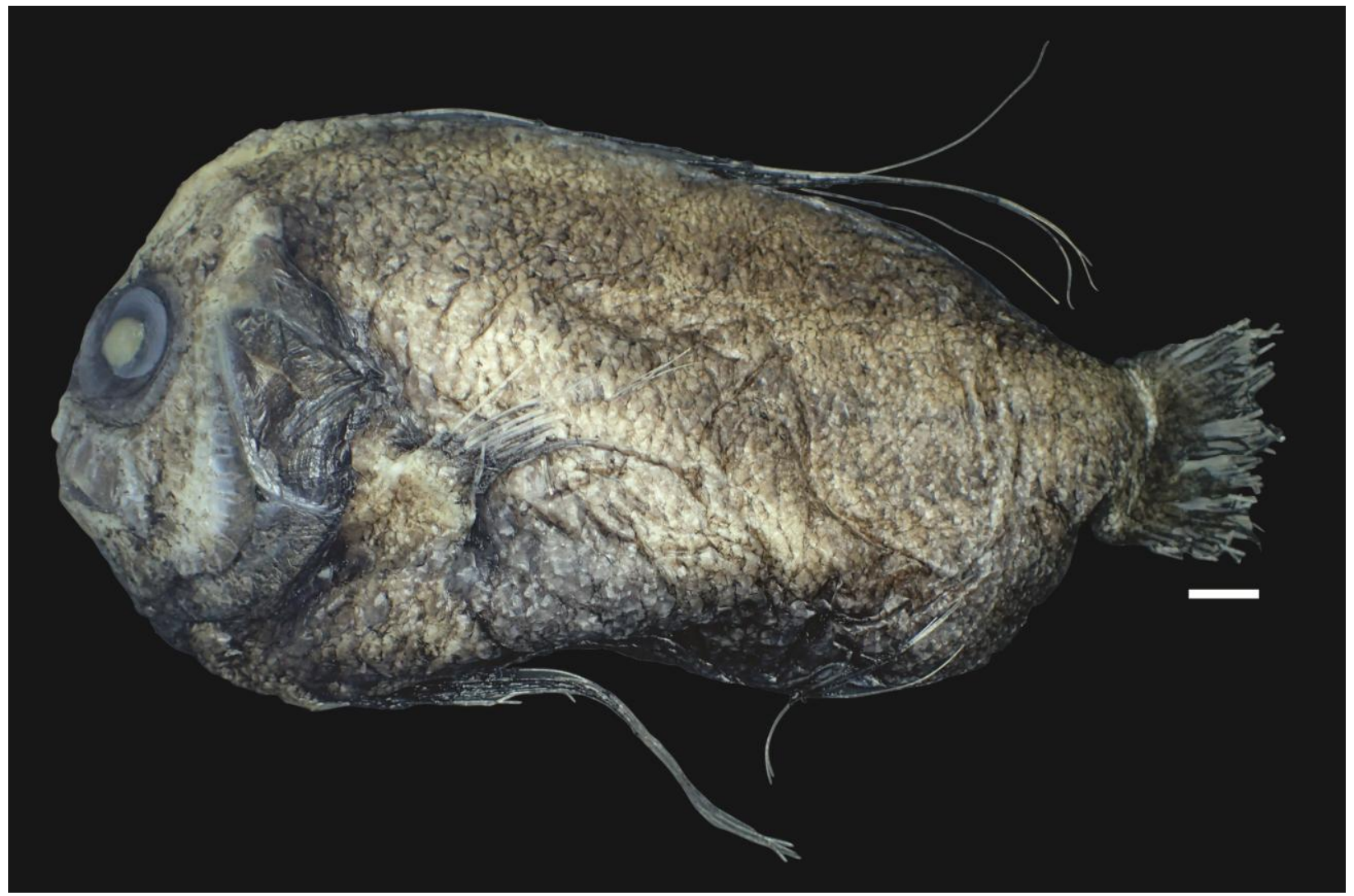

313

314 Figure 1. Paracaristius nudarcus (NPM 4476, $165 \mathrm{~mm} \mathrm{SL}$ ). Scale $=10 \mathrm{~mm}$. 


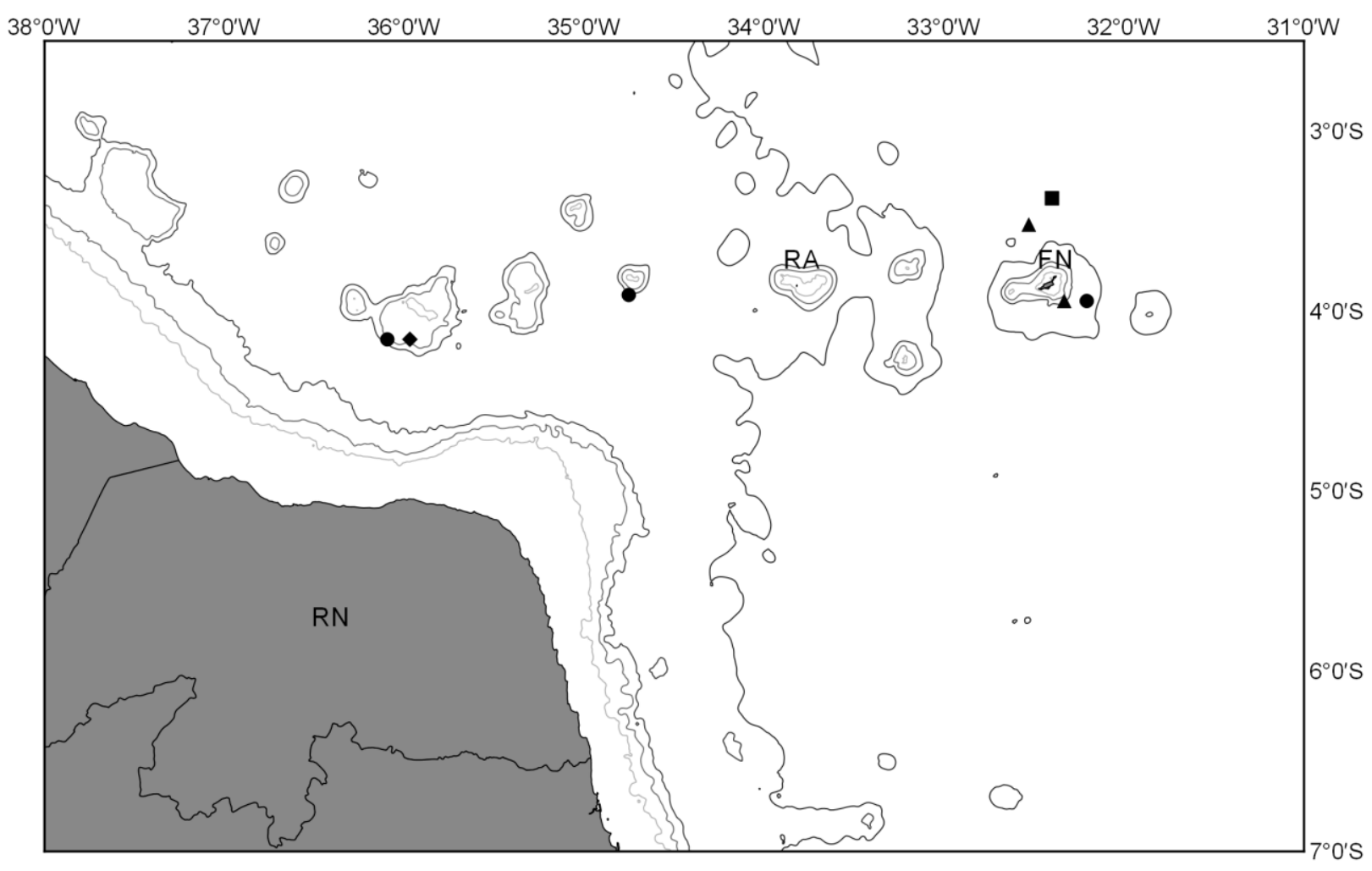

325

326 Figure 2. Distribution of fishes of the family Caristiidae around oceanic islands and seamounts 327 off northeastern Brazil: Paracaristius nudarcus ( ), Platyberyx andriashevi ( ), Platyberyx 328 paucus ( ), and Platyberyx pietschi ( ). RN - State of Rio Grande do Norte; RA - Rocas Atoll; 329 FN - Fernando de Noronha Archipelago. 


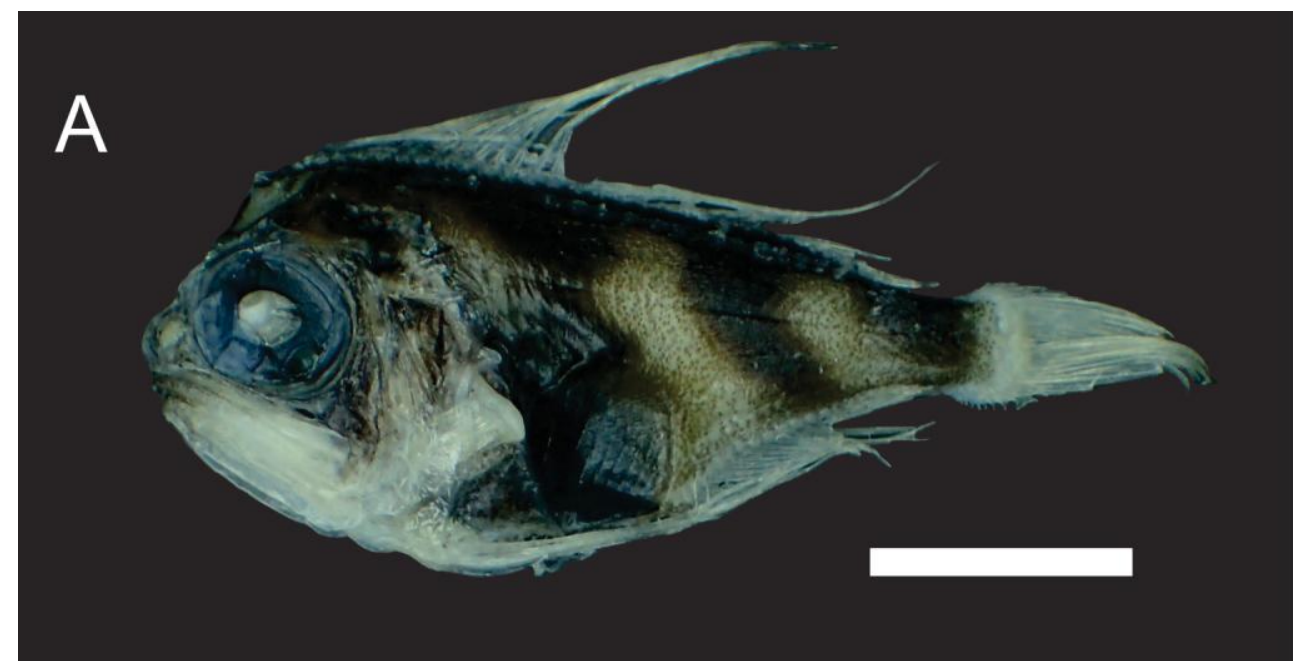

\section{B}

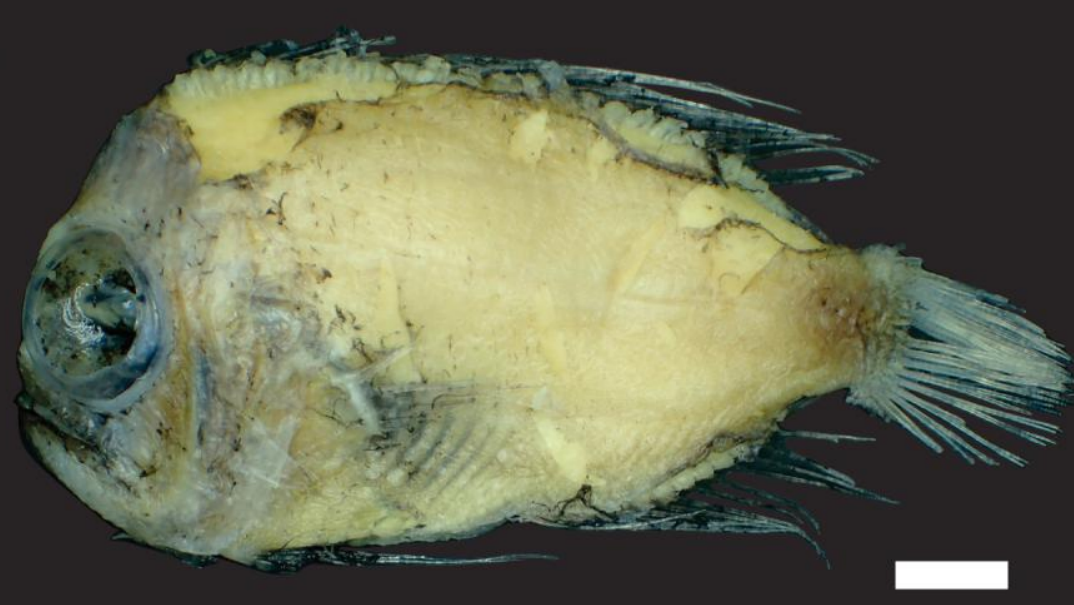

C

Figure 3. A- Platyberyx andriashevi (NPM XXXX, XXX mm SL), B- Platyberyx paucus (NPM XXXX, XXX mm SL), and C- Platyberyx pietschi (NPM 4510, $72 \mathrm{~mm} \mathrm{SL}$ ). Scale $=10 \mathrm{~mm}$. 
345 Table I. Proportions and counts for Paracaristius nudarcus, Platyberyx andriashevi, Platyberyx 346 paucus and Platyberyx pietschi collected off northeastern Brazil (western South Atlantic) and 347 compared with those reported in the literature. 


\begin{tabular}{|c|c|c|c|c|c|c|c|c|}
\hline \multirow{2}{*}{$\begin{array}{l}\text { Species } \\
\text { References }\end{array}$} & \multicolumn{2}{|c|}{ Paracaristius nudarcus } & \multicolumn{2}{|c|}{ Platyberyx andriashevi } & \multicolumn{2}{|c|}{ Platyberyx раисиs } & \multicolumn{2}{|c|}{ Platyberyx pietschi } \\
\hline & $\begin{array}{c}\text { Present } \\
\text { study }\end{array}$ & $\begin{array}{c}\text { Stevenson \& } \\
\text { Kenaley }(2011)\end{array}$ & $\begin{array}{l}\text { Present } \\
\text { study }\end{array}$ & $\begin{array}{c}\text { Stevenson \& } \\
\text { Kenaley (2013) }\end{array}$ & $\begin{array}{l}\text { Present } \\
\text { study }\end{array}$ & $\begin{array}{c}\text { Stevenson \& } \\
\text { Kenaley (2013) }\end{array}$ & $\begin{array}{c}\text { Present } \\
\text { study }\end{array}$ & $\begin{array}{c}\text { Stevenson' } \\
\text { Kenaley (2013) }\end{array}$ \\
\hline Standard length (SL, mm) & $165(1)$ & $22-223(17)$ & $23-138(3)$ & $32-196(18)$ & $85-97(3)$ & $21-100(4)$ & $72(1)$ & $34-93(4)$ \\
\hline Vertebrae & $37(1)$ & $33-37(16)$ & $37-39(3)$ & $36-39(16)$ & $31-32(3)$ & $31(4)$ & $33(1)$ & $33-35(3)$ \\
\hline Dorsal-fin rays & $28(1)$ & $27-31(17)$ & $31-35(3)$ & $31-35(16)$ & $25-26(3)$ & $24-26(4)$ & $30(1)$ & $30-31(3)$ \\
\hline Anal-fin rays & $18(1)$ & $17-20(17)$ & $21-22(3)$ & $20-22(16)$ & $15-17(3)$ & $15-16(4)$ & $17(1)$ & $18-19(4)$ \\
\hline Pectoral-fin rays & $16(1)$ & $16-18(15)$ & $19(3)$ & $17-18(16)$ & $16-17(3)$ & $16-17(4)$ & $18(1)$ & $17-18(4)$ \\
\hline Vomerine teeth & Absent & Absent & 4-7 (3) & $3-12(15)$ & $5(1)$ & $1-6(4)$ & $8(1)$ & $8-10(4)$ \\
\hline Palatine teeth & Absent & Absent & $4-12(3)$ & $3-12(15)$ & Absent & Absent & - & $6-10(4)$ \\
\hline Upper jaw teeth & - & $24-43(10)$ & $16-22(3)$ & $12-35(12)$ & $42-43(2)$ & $42(1)$ & $48(1)$ & $32-45(3)$ \\
\hline Lower jaw teeth & - & $16-36(7)$ & $19-27(2)$ & $11-26(7)$ & $42-53(2)$ & $37(1)$ & $20(1)$ & $16-30(2)$ \\
\hline Upper gill rakers & $8(1)$ & $5-8(16)$ & $7-8(3)$ & $5-8(15)$ & $7(3)$ & $6-7(4)$ & $7(1)$ & $6-7(4)$ \\
\hline Lower gill rakers & $15(1)$ & $14-16(16)$ & $11-14(3)$ & $12-15(15)$ & $14-15(3)$ & $14-16(4)$ & $13(1)$ & $13-14(4)$ \\
\hline Total gill rakers & $23(1)$ & $20-24(16)$ & $18-22(3)$ & $18-22(15)$ & $21-22(3)$ & $21-23(4)$ & $20(1)$ & $19-21(4)$ \\
\hline \multicolumn{9}{|l|}{ Measurements in \% of $S L$} \\
\hline Body depth & $58.2(1)$ & $53.0-77.0(15)$ & $45.7-48.5(2)$ & $37.9-49.6(18)$ & $55.4-57.1(3)$ & $52.1-68.3(4)$ & $53.75(1)$ & $45.6-53.0(4)$ \\
\hline Head length & $32.2(1)$ & $29.0-45.7(14)$ & $28.6-40.6(2)$ & 24.2-39.9 (18) & $36.7-38.8(3)$ & $39.9-54.1(3)$ & $38.9(1)$ & $33.4-41.3(4)$ \\
\hline Predorsal length & $31.5(1)$ & - & $25.7-30.3(2)$ & - & $34.5-37.2(3)$ & - & $34.7(1)$ & - \\
\hline Predorsal length (horizontal) & $12.1(1)$ & $6.5-17.9(15)$ & 9.4-11.5 (2) & $8.3-22.3(18)$ & $16.5-23.7(3)$ & $17.2-29.0(3)$ & $18.9(1)$ & $16.9-25.9(4)$ \\
\hline Prepectoral length & $34.5(1)$ & $30.4-42.2(12)$ & $28.6-37.9(2)$ & $11.6-42.8(18)$ & $38.2-44.8(3)$ & $45.8-53.9(3)$ & $41.3(1)$ & 39.6-44.4 (4) \\
\hline Prepelvic length & $30.6(1)$ & $30.5-42.1(15)$ & $25.5-33.3(2)$ & $22.4-39.6(18)$ & $30.6-38.7(3)$ & $39.3-49.4(3)$ & $38.9(1)$ & $36.1-52.7(4)$ \\
\hline Pectoral-fin base & $7.9(1)$ & $6.4-11.9(15)$ & $6.9-9.1(2)$ & 5.3-11.5 (17) & $7.1-11.0(3)$ & 7.8-10.6 (4) & $9.0(1)$ & $7.1-9.7(4)$ \\
\hline Preanal length & $59.7(1)$ & $55.5-70.9(15)$ & $43.0-60.6(2)$ & $44.6-58.1(18)$ & $59.3-62.4(3)$ & $65.3-72.9(3)$ & $58.1(1)$ & $54.5-64.7(4)$ \\
\hline Dorsal-fin base & $77.6(1)$ & $72.2-86.3(15)$ & 75.8-79.7 (2) & $65.9-80.8(18)$ & $62.9-73.8(3)$ & $61.0-71.7(4)$ & $73.6(1)$ & 62.9-68.7 (4) \\
\hline Anal-fin base & $43.3(1)$ & $34.1-49.6(15)$ & $31.8-47.6(2)$ & $31.6-53.3(18)$ & $34.1-35.7(3)$ & $29.1-37.7(4)$ & $33.3(1)$ & $28.7-37.3(4)$ \\
\hline Peduncle length & $16.5(1)$ & $10.9-16.5(15)$ & $8.5-13.0(2)$ & $12.0-18.9(18)$ & $13.9-17.0(3)$ & $12.1-14.8(4)$ & $13.9(1)$ & $13.5-17.4(4)$ \\
\hline Peduncle depth & $15.8(1)$ & $12.8-17.7(15)$ & $10.3-10.9(2)$ & $8.5-12.8(18)$ & $14.4-15.9(3)$ & $14.5-16.6(4)$ & $12.5(1)$ & $10.7-14.6(4)$ \\
\hline Head length (HL, mm) & $53.2(1)$ & - & $13.4-39.5(2)$ & - & $32.8-35.6(3)$ & - & $20.0(1)$ & - \\
\hline \multicolumn{9}{|l|}{ Measurements in \% of $H L$} \\
\hline Upper jaw length & $37.6(1)$ & $34.7-52.8(13)$ & 64.3-68.7 (2) & $58.8-74.7(18)$ & $45.3-51.8(3)$ & $49.8-71.0(3)$ & $67.9(1)$ & 58.6-69.4 (4) \\
\hline Lower jaw length & $36.7(1)$ & $39.3-50.4(13)$ & $51.4-54.5(2)$ & $52.2-84.6(18)$ & $39.7-46.1(3)$ & $48.8-57.3(2)$ & $42.9(1)$ & $55.6-70.7(4)$ \\
\hline Bony orbit length & $38.3(1)$ & $33.1-45.5(14)$ & $45.6-52.2(2)$ & $40.0-52.6(18)$ & $44.8-50.6(3)$ & $49.1-51.4(3)$ & $46.4(1)$ & $43.7-51.9(4)$ \\
\hline Preorbital length & $22.6(1)$ & - & $14.9-17.7(2)$ & - & $16.8-20.2(3)$ & - & $17.9(1)$ & - \\
\hline $\begin{array}{l}\text { Preorbital length } \\
\text { (horizontal) }\end{array}$ & $13.2(1)$ & 6.5-17.4 (14) & $14.4-14.9(2)$ & - & 7.6-11.2(3) & - & $10.7(1)$ & - \\
\hline
\end{tabular}

